\title{
Hitting the Headlines and Falling Down Again: Newspaper Coverage of Climate Change in Finland
}

\author{
Jari Lyytimäki \\ Finnish Environment Institute \\ Environmental policy centre \\ Finland
}

\section{Introduction}

Many of the current environmental problems are cross-national. Perhaps the best example is anthropogenic climate change that is altering climatic conditions and ecosystem services and thus affecting economic, political and social structures of human communities throughout the world (Intergovernmental Panel on Climate Change [IPCC], 2008; Millennium Ecosystem Assessment [MEA], 2005).

The transnational character of many environmental problems is further emphasised by their connections with various other globalization processes. These include, e.g. global trade with long production and consumption chains and the creation of global product brands, advertising, and marketing (Lebel \& Lorek, 2008). Global consolidation of media ownership, development of new information and communication technologies detached from place, and the increasing use of English are key trends of the globalization of the media (Hopper, 2007).

Climate change has been recognised as a key concern by an overwhelming majority of scientists (Oreskes, 2004) and by a growing amount of policy-makers, businessmen and citizens. However, the public and policy concern over climate change is unevenly distributed between and within countries. One explanation for the country-by-country differences is the variation of quantity and quality of mass media coverage. Media visibility and the framings can vary considerably. This was shown by the media treatment of the international climate negotiations of the United Nations Framework Convention on Climate Change (UNFCCC) in Bali 2008 (Eide et al., 2009) or Copenhagen 2009 (Painter, 2010) that varied across countries despite the commonly shared objects of news reporting. The high visibility of climate sceptics or climate contrarians in the US mainstream media compared to European countries such as Finland is another example (Boykoff \& Boykoff, 2007; UusiRauva \& Tienari, 2010).

National level media institutions combine international influences with local practices determined by social, political, economic and ecological contexts (Olausson, 2009; Adelekan, 2009). For example, the comparison between the commercially oriented US media system and public service oriented system, such as in Finland, shows that public service television devotes more attention to public affairs and international news, and fosters greater knowledge in these areas (Curran et al., 2009). 
Different languages are one factor creating local level variation and diversity to the social construction of global environmental issues. Most of the studies of the climate change media coverage - and environmental coverage more generally - focus on the English language material, especially to the US news coverage (Boyce \& Lewis, 2009; Boykoff, 2009). Analyses of climate coverage in vernacular languages other than English are relatively scarce. Furthermore, many of these analyses are published in "grey literature" written in national languages and therefore their availability to international audience is limited (Lyytimäki \& Palosaari, 2004; Lyytimäki \& Tapio, 2009).

More cross-national analyses of climate change media coverage has been called for in order to discover similarities and dissimilarities in the information and interpretations that people in various countries receive (Dirikx \& Gelders, 2009). The aim of this paper is to generate one missing piece to this puzzle by outlining the development of long-term media coverage of climate change in Finland and by identifying critical discourse moments related to the Finnish climate debate.

Here critical discourse moments are understood as key turning points of the quantity or qualities of the media coverage (Gamson, 1992; Carvalho \& Burgess, 2005). First, the early development of the Finnish climate debate is reviewed in order to give background and to contextualise the Finnish case. Second, climate coverage is reviewed trough a content analysis of the leading national level newspaper from the period of 1990-2010. The analysis is partly based on material collected for previous studies (Lyytimäki \& Tapio, 2009; Lyytimäki, 2011).

Finnish is spoken as a first language by five million people, almost all of them in Finland. Because of the small population, the direct impacts of activities in Finland to the global environmental problems such as the climate change are relatively limited. However, Finland serves as a potentially interesting case since the per capita environmental impacts of the Finns are considerable (Seppälä et al., 2009). On the other hand, Finland is considered as one of the forerunners of environmental protection and sustainability issues (Udo \& Jansson, 2009). The Finnish case may provide relevant insights on the local level debate over global environmental problems such as the climate change, but caution is needed when comparisons are made with other countries.

\section{Research material}

This paper is based on a literature review synthesizing earlier studies on the climate debate in Finland - most of them published in Finnish - and a content analysis of newspaper coverage. The literature review included both international and national literature. In addition, the archives of selected Finnish university departments were screened since many of the earlier studies of the topic were conducted as master's thesis or doctoral dissertations. A bibliography of environmental communication research served as an additional source (Lyytimäki \& Palosaari, 2004).

The media content analysis is based on data from the broadsheet Helsingin Sanomat (HS). HS is the leading national-level newspaper in Finland and it has a major influence on public and policy agenda (Suhonen, 1994; Herkman, 2010). It can be characterised as a "prestige" newspaper. Despite the growing use and influence of electronic media, newspapers remain an important source of environmental information in Finland (Ekholm et al., 2007; Kiljunen, 2010). The circulation of HS has slightly declined during the recent years but it still stands at about 400000 copies daily and about one million readers, i.e. almost a fifth of the entire 
population (Finnish Audit Bureau of Circulations [FABC], 2010). Furthermore, the internet site of the newspaper is one of the most popular in Finland.

The data on news coverage were collected from the online database of HS (http://www.hs.fi/arkisto). This electronic archive contains material published by the newspaper from 1990 onwards. It includes the titles and texts of the printed material, including news articles as well as Letters to the Editor, columns and commentaries. Information on pictures, picture captions, graphics and other visual illustrations, cartoons and advertisements is not included. The weekly supplement (NYT-liite) concentrating mainly on TV-programs and entertainment and the supplementary monthly magazine (Kuukausiliite) are also excluded.

After testing different keywords (see Lyytimäki \& Tapio, 2009), the search string "climate change" (ilmastonmuutos) was used. In Finnish, the search term "global warming" is not suitable, since there is no corresponding and widely used direct translation for it. The accuracy of search results was checked. Only few references unrelated to climate issues were found, but the amount of duplicates typically resulting from the inclusion of different editions of the newspaper was substantial. The highest yearly percentage of duplicates was $33 \%$ from year 1990 . During the 2000s the yearly share of duplicates was $5 \%$ or less.

\section{Early climate debate in Finland}

It took a relatively long time before the warming of the global climate due to anthropogenic climate change became a widely acknowledged environmental problem in Finland. The potential of carbon dioxide, released to the atmosphere from human activities, to increase the global temperature was first mentioned on the pages of HS in the 1950s (Karppinen, 1993). For example, in 1958, one news story published by the HS focused on the potential effects of nuclear weapon testing to weather. The article concluded that such effects do not exist but mentioned that the strengthening of the greenhouse effect is likely to increase the global temperature by $1^{\circ} \mathrm{C}$ (Lähteenmäki, 2006).

With the exception of occasional news items mentioning the subject, the climate change remained almost absent from public debate until the 1970s (Rinne, 2003). Both in Finland and internationally, most experts and the general public found it difficult to believe that human activities could alter the climate of the planet as a whole (Weart, 2008). Warming of the climate was especially difficult to perceive as a threat in a Northern country characterised by long and cold winters, with spring and autumn frosts threatening the harvests. The individual speculations about the issue typically welcomed the potential warming as a positive development. Already in the 18th century the educated Finnish clergy had speculated that agricultural practices modifying the Earth - and thus fulfilling the God's will - could improve the harsh weather conditions (Niemelä, 2008).

Finland was predominantly an agricultural country until 1950s. A majority of Finns had first-hand experiences of the deleterious impacts of unfavourable weather to food production and livelihoods. Finnish industrialisation progressed rapidly during 1950s and 1960s, causing an increase of greenhouse gas emissions. The carbon dioxide emissions from the use of fossil fuels increased from about five million tonnes in late 1930s to about 50 million tonnes in late 1960s (Kunnas, 2009).

As the economic prosperity increased, the social structures of the Finnish society and lifestyles of the people faced dramatic changes. For example, from mid-1960s onwards package tour flights directed typically to the Canary Islands and Southern Europe become 
increasingly available for Finns. Related to this, sun-bathing on warm beaches became a common theme of newspaper travel advertisements (Juutilainen, 2001). Thus, warm climate was increasingly connected with positive connotations such as leisure time and high social status.

During the 1970s, global warming was a non-problem also because the weather statistics did not indicate a warming of climate but rather a continuation of a relatively cool period following the warm period of the 1930s (Jylhä et al., 2004). Instead, the fears related to the cooling of the climate were emphasised (Weart, 2008; Lyytimäki, 2009). On the one hand, these fears were connected to the speculations suggesting the possibility of a new Ice Age looming somewhere in the distant future. On the other hand, they were related to the risk of "nuclear winter" resulting from large scale use of nuclear weapons in the context of the Cold War. In the early 1980s, additional interest towards global cooling was raised by scientific findings suggesting that global cooling which resulted from the global dust cloud caused by an asteroid collision to Earth was partially responsible for the great mass extinction 65 million years ago (Alvarez et al., 1980). However, instead of climate debate, this finding was primarily linked to the debate on current loss of biodiversity caused by human activities.

During the late 1980s the number of news items dealing with global warming and other issues related to climate and air protection increased in the Finnish press (Heiskala, 1993; Suhonen, 1994). In the mid-1980s, environmental coverage in foreign news pages of HS increased as the number of news items quadrupled from about 50 to about 200 news items annually. This was partially explained by the coverage given to the Chernobyl nuclear accident (1986). Other international key topics of the 1980s and 1990s included the greenhouse effect, destruction of rainforests, stratospheric ozone depletion, and the environmental problems of the Eastern Europe that were caused primarily by heavy industry and energy production. Related to this, the debate over acidifying precipitation, or "acid rain", and the Central European "forest deaths" highlighted the cross-border characteristics of air pollution (Väliverronen, 1996).

In the late 1980s, consensus over the climate change was largely missing. In order to answer the need for a science-based synthesis, the United Nations Environment Programme (UNEP) and the World Meteorological Organization (WMO) established the Intergovernmental Panel on Climate Change (IPCC) in 1988. Since the first reports published in 1990, the IPCC has been a key source of climate information. The year 1988 has been identified as a turning point of the global debate on climate change also because of the hot and dry summer in the USA (Ungar, 1992). The scientific theories were now backed up by concrete extreme weather events, and the wide-scale debate was triggered by the testimony of Dr James Hansen in the US Congress. The weather anomalies in the North America and elsewhere were reported as signs of global warming by the Finnish media as well (Kantola, 1996).

\section{Coverage of climate change during 1990-2010}

Between January 1990 and December 2010, almost 5,500 news stories mentioning climate change appeared in the pages of HS (Fig. 1). Generally, the news coverage was characterised by short-term ups and downs and a relatively low level of attention to climate change until the mid 2000s. Between 1990 and 2005, only 7.5 news stories mentioning climate change appeared per month. This was partly because climate issues were largely treated under the 
label of "greenhouse effect" especially in the 1990s (Suhonen, 1994). In 2006, the monthly average increased to 34.3, and during 2007-2009, the monthly average reached 84.2. In 2010, the monthly average dropped to 46.2. The development of climate news in other Finnish broadsheet newspapers has generally followed the same pattern (Lyytimäki, 2011).

About a fourth of the HS news items mentioning climate change were published in the letters to the editor pages $(16.8 \%)$ or in the editorial section $(10.1 \%)$. In addition to editorials by the newspaper staff, viewpoint articles by external expert writers are published in the editorial section. Domestic news pages $(15.2 \%)$ and foreign news pages $(15.4 \%)$ hold almost identical share of the news. Despite the global perspective inherent to climate issues, $6.9 \%$ of the news items appeared in sections focusing on local issues.

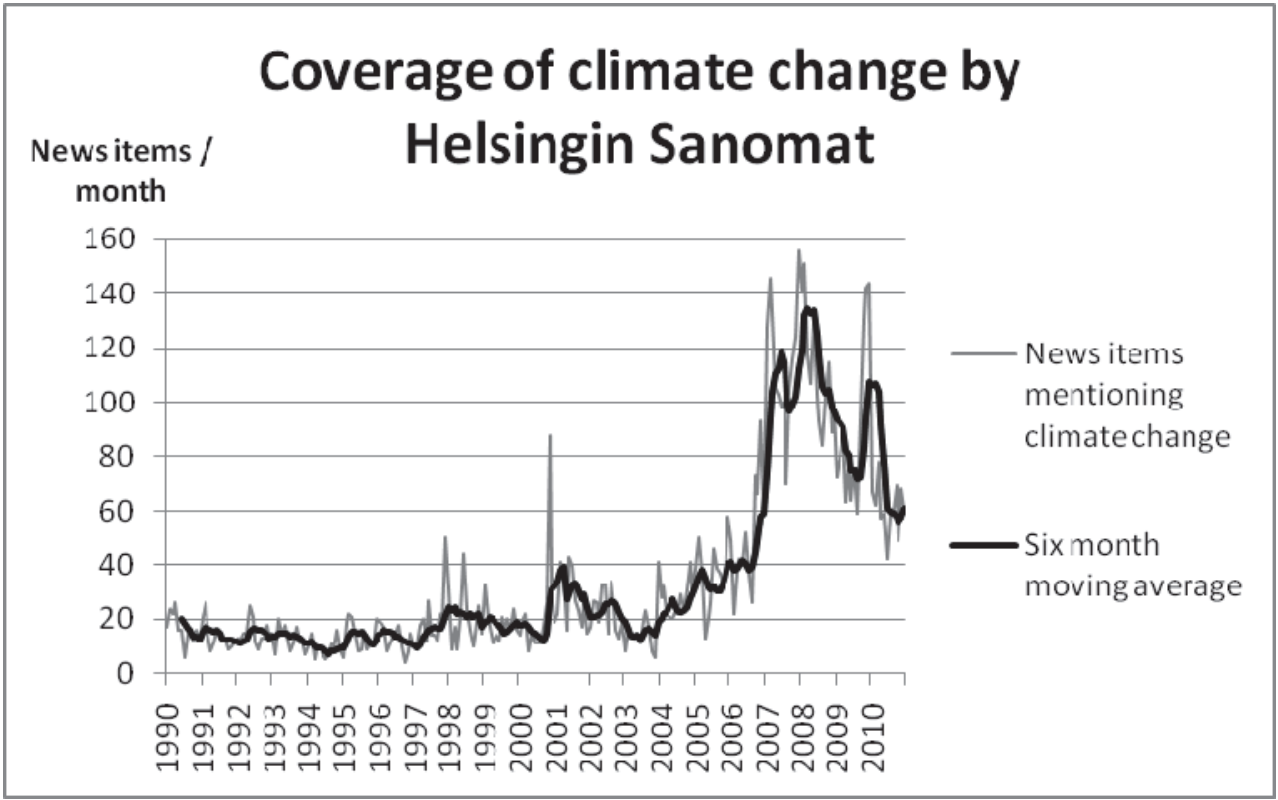

Fig. 1. Overall development of the climate news. Monthly number of news items mentioning climate change and a 6-month moving average, 1990-2010 (Modified from Lyytimäki \& Tapio 2009; Lyytimäki, 2011).

Internationally, the media coverage of environmental issues was on a relatively high level in the late 1980s but the coverage receded in the early 1990's (Mazur, 1998; Carvalho \& Burgess, 2005; Boykoff, 2009). One of the key events of the period was the 1992 UN Conference on Environment and Development (UNCED) in Rio de Janeiro, Brazil. Outcomes of the conference included the UN Framework Convention on Climate Change (UNFCCC) that formed the basis for the subsequent international climate policies. However, the conference concentrated on a variety of environmental and sustainability topics and it did not show as a clear peak in the Finnish climate coverage.

A peak in climate coverage occurred in November-December 1997 due to the third Conference of the Parties (COP3) of the UNFCCC meeting in Kyoto, Japan. After heated negotiations, this meeting ended up with the Kyoto protocol that included concrete targets 
for global climate policies. The Kyoto meeting can be considered as a turning point in Finnish climate change policies (Tirkkonen, 2000; Perimäki, 2002). Finland signed the Kyoto protocol in 1998 and ratified it together with 14 other EU member states in 2002. The implications of the Kyoto protocol for the Finnish economy were discussed on various occasions during late 1990s. This debate was mainly connected to the so-called burden sharing between the EU Member states. The country specific target set for Finland was to freeze the emissions of major greenhouse gases at the level of 1990 for the period of 20082012. Since the key issues were already settled, the media attention was scarce when the Kyoto protocol entered into force on the 16 February 2005. The issue was noticed by the HS (e.g. HS February 15, 2005), but without a major discussion on the effects of the protocol.

Various policy issues related to the energy issues and global climate policies dominated the climate debate during the autumn 2000 (Kerkkänen, 2010). The most distinctive event was the failure of international climate negotiations in the COP6 meeting in Hague, the Netherlands. The November 2000 peak of coverage was also connected to the application sent to the Finnish Parliament for a permission to build the 5th nuclear reactor in Finland by the energy company TVO. International negotiations were also connected to the national level preparations of the government's climate strategy.

The climate coverage decreased during 2001-2004 (on average, 11.4 news items per month). At the start of the 2001, a disagreement between key politicians over the potential costs of climate policy received attention. At the end of 2005, a rise in coverage occurred partly related to the COP11 meeting in Montreal, Canada, followed by a temporary drop in early 2006. Growth of coverage continued later in 2006. During the autumn 2006, the focus of news was clearly on international issues. For example, a series of news labelled "changing climate" and focusing on the effects of climate change on people and nature around the world was published on the HS foreign news pages.

Two major documents that gained wide international attention were published during the autumn 2006. These were treated very differently by the HS. Release of the "Stern report" on the economics of climate change (Stern, 2007) was reported in the news front page and in the economy pages (HS October 31, 2006) in a serious tone as a well-reasoned warning of a respected economist. On the other hand, the documentary film An Inconvenient Truth by $\mathrm{Al}$ Gore was treated on the economy pages with a critical and even sarcastic tone as "...a kind of extended PowerPoint presentation that was awarded at the Cannes film festivals." (HS 6 September 2006). The HS presented Al Gore as the "leading preacher of global warming" and a columnist invited to evaluate Gore's presentation in Helsinki nicknamed him as "Al Bore" because he presented too many graphs (HS 6 September, 2006).

A sharp increase of coverage occurred in January 2007. No single dominant news topic can be attributed for this increase. Several letters to editor related to energy policy were published as well as various other expressions of concern related to climate risks. Domestic and foreign news pages focused on news related to research results, climate policies and weather anomalies. In the end of the January, an interview of Mr Jorma Ollila, chairman of the Nokia corporation and the Royal Dutch Shell was published (HS January 28, 2007). This interview can be considered as a distinctive turning point, since it clearly articulated the concern over climate change by a key economic actor and an opinion leader. Mr Ollila urged for fast reductions of carbon dioxide emissions and asserted that "the big European energy and oil companies have already accepted that climate change is caused by human beings". The high level of coverage was sustained in February 2007 when the EU initially declared its climate package, introducing a target of $20 \%$ reduction of greenhouse gas emissions by 2020 
(HS February 21, 2007) (see also Uusi-Rauva \& Tienari, 2010). The debate was further fuelled because of the estimation by the Government's Economic Research Institute that fulfilling the EU targets would cost the loss of employment of some 60000 Finns (HS February 20, 2007). Other key news included the publication of the IPCC summary report. The title on the front news page highlighted and dramatised the risks: "Report: The Finnish climate can get even 9 degrees warmer" (HS February 3, 2007). Furthermore, the news included a statement from the Prime Minister Matti Vanhanen that the "downplaying of the climate change has to be stopped immediately".

During the following months, the coverage began to decrease, but it increased again during the following autumn and winter. The Nobel peace prize given to Al Gore and IPCC fuelled the debate (HS October 23, 2007). Individual critical news were also published about the decision of British court on mistakes in Gore's documentary film An Inconvenient Truth (HS October 12, 2007).

In December 2007, the COP13 meeting in Bali, Indonesia, received considerable international news coverage (Eide et al., 2009). The HS summarised the meeting with the title "Vaulting drama ended with climate concord in Bali" (HS December 16, 2007). However, this meeting did not cause a major shift in the Finnish climate debate although the news coverage remained at a high level during the following months. Importantly, the mild winter weather and the lack of snow gave journalists a convenient passage for presenting climate issues connected with various news topics (Lyytimäki \& Tapio, 2009).

The most dramatic monthly decrease of coverage occurred during January 2010. This can be explained by the preceding peak of coverage caused by the COP15 meeting held in Copenhagen, Denmark. Unusually high expectations directed to the meeting created a sense of drama, increasing journalistic interest in the meeting. As measured by the number of journalists attending, the Copenhagen meeting was more popular than the Rio de Janeiro UNCED meeting in 1992 or the Kyoto COP3 meeting in 1997 (Painter, 2010). The aim of the Copenhagen meeting was to agree on the global climate policies after the Kyoto protocol. However, in Finland the COP15 peak of coverage appears to be substantially lower than in several other countries (Boykoff \& Mansfield; 2010; Painter, 2010). During the COP15 meeting, the climate coverage of HS reached about the same level than in January-February 2007 and January 2008.

Despite the peak related to the COP15 meeting, the yearly amount of climate news decreased in 2009. This can partly be explained by the global financial crisis and economic slowdown that spread to the Finnish economy and reduced public interest in environmental issues. After the two mild winters, there was also more normal weather during the winter of 2009-2010, as the whole of Finland was covered in snow (Lyytimäki \& Tapio, 2009). Only one small news item (HS February 16, 2010) noted that despite the cold weather in Europe and eastern parts of North America, globally the weather was exceptionally warm in January 2010 (National Oceanic and Atmospheric Administration [NOAA], 2010).

The summer of 2010 was record-breaking hot, and November and December 2010 were unusually cold in Finland. However, these weather anomalies were not strongly connected to the climate change by the HS.

\section{Discussion}

Recent decline of climate change news coverage can be understood as an outcome of several intertwined factors. The two unusually snowy winters suggested no warming and made it 
easy for journalists to ignore research results and policy processes related to climate change. Furthermore, the global economic crisis that hit also the Finnish economy was perceived as a more serious and immediate problem.

The economic slowdown and cold winters were presented as possible explanations for the results of an opinion poll showing that $48 \%$ of the Finns considered that the effects of climate change had been exaggerated (YLE, 2010). This opinion poll ( $\mathrm{N}=1007)$ was conducted in March 2010. Another opinion poll, reported by the HS in April 14, 2010, indicated that the share of the Finns who fully agree that the climate change is the greatest environmental threat requiring rapid actions dropped from $51 \%$ in winter 2009 to $32 \%$ in winter 2010 (Haavisto, 2010). Yet another opinion poll indicated that the willingness of the Finns to pay for climate actions decreased already in 2009 (HS October 8, 2009). The Finnish Science Barometer indicated that the share of the people who fully agree that the continuation of climate change is a real and serious threat that requires efficient actions from the decision makers dropped from 59\% in 2007 to 42\% in 2010 (Kiljunen, 2010).

Lack of progress of climate policies showed the difficulties of finding the solutions to climate problems and perhaps contributed to a sense of helplessness and apathy (Sairinen et al., 2010). Additional possible explanation is the decrease of interest of both journalists and the public - a climate fatigue - following the period of intense debate. For example, in a letter to the editor (HS April 21, 2009), the author rearticulated a deeply rooted popular belief of the beneficial warming by asserting that "people are getting fed up with the onesided doomsday predictions. Common sense tells us that the warming of climate is a good thing in the Nordic countries."

From the November 2009 onwards, scepticism towards climate change increased due to the so-called "climategate" and "Himalayagate" episodes (Berkhout, 2010; Nerlich, 2010; Painter, 2010). However, despite some critique presented especially in the letters to the editor, the news coverage of HS was dominated by views favourable to IPCC and other actors stressing the seriousness of climate change and general trustworthiness of climate science. For example, when reporting on the forthcoming review of the IPCC reports, HS (April 12, 2010) mentioned the critique only briefly and gave more space to the UN Secretary-General Ban Ki-moon who assured that "Let me be clear - the threat posed by climate change is real ... None of the recent accusations or disclosures by the media alters the scientific consensus on climate change." Thus, the Finnish coverage appear to resemble other European countries, such as Sweden (Olausson, 2009), Germany (von Storch and Krauss, 2005) and France and the Netherlands (Dirikx \& Gelders, 2009) where the visibility of so called climate sceptics has been low, in contrast with the US climate debate (Armitage, 2005; Boykoff \& Boykoff, 2007).

The decrease of the climate change coverage suggests a shift to some kind of post-problem stage. One of the most widely applied models that aim to explain the fluctuation of news coverage is the Issue-Attention Model (Downs, 1972; Brossard et al., 2004). The model assumes an initial pre-problem stage where environmental problem exists but has yet to capture public attention. The second stage is characterised by dramatic events that make the public both aware of the problem and alarmed about it. The "gradual-realization-of-the-cost stage" is the third phase where key actors acknowledge costs that will be incurred in dealing with the problem. This phase is followed by gradual decline of interest as actors become discouraged at the prospect of appropriately dealing with the issue, and finally a postproblem stage of low attention to the issue. 
However, this model fails to address the fact that despite the decrease of coverage after the peak(s), climate issues are still featured more extensively than in the 1990s and early 2000s. The current Finnish debate can hardly be described as a post-problem phase where the issue once elevated to national prominence may sporadically recapture public interest (Downs, 1972). Instead, it appears that the relatively large-scale treatment of climate issues continue and climate issues are also treated under other topics such as energy policies (Teräväinen, 2010) or traffic (Rinkinen, 2010). Climate issues are also widely addressed in culture and lifestyle pages of the HS and arguments related to the climate change are used in advertisements, as well (Reineck, 2009).

Theories and models focusing on shifts between alternative states of a system with different qualitative properties appear to provide useful additional tools to understand the changes of the Finnish climate debate. The changes between the stages of public discourse as described by the Issue-Attention Model may be the result of a punctuation processes (Holt \& Barkemeyer, 2010). Punctuated Equilibria Model focuses on systems that are characterised by a period of stasis, which are later punctuated by sudden shifts. The model has been widely applied. It has been suggested to describe the biological evolution in geological time scales (Eldredge \& Gould, 1972) as well as the evolution of US policy agenda (Baumgartner \& Jones, 1993). As Holt and Barkemeyer (2010) note, most explorations of punctuated equilibrium associate some form of an exogenous shock that affect the system.

Critical discourse moments can be understood as manifestations of shocks affecting a system. The most distinctive critical discourse moment identified from the Finnish climate coverage occurred in January 2007. The driving forces behind this moment of increased interest included a combination of national and international factors. On a national level, key factors were the mild and snowless winter weather and the expression of concern of an opinion leader. International factors included the publication of the IPCC report that continued the discussion on the recently published Stern report and other international and national level studies related to climate change. After this period of heightened coverage, the climate change was widely accepted as a serious policy concern.

To summarise, it any model explaining the increases and decreases of environmental coverage should take into account both ecological socio-economic factors influencing the coverage, and combine local contexts with relevant global processes. Humility is needed since it is unlikely that any single model is able to take into account all relevant variables and the wide variation of contributing factors in different contexts. For example, while the issue-attention model appears to hold in some contexts, it does not hold in others (Brossard et al. 2004). Instead of aiming for one universal model, the fruitful approach for future research is to aim at case-specific combination of different models that can best explain the global-local interactions affecting the evolution of environmental media coverage in their unique contexts.

\section{Conclusion}

Largely because of the heightened media coverage, the global climate change has emerged as the key environmental concern of the early 21st century. The media reporting on environmental issues is a part of a complex web of global and local social, economic, cultural, and ecological processes. It can reflect changes in ecological environment, but only rarely in a linear fashion; ecological changes usually do not result in corresponding changes of news coverage (Ader, 1995; Lyytimäki, 2007; Mazur, 2009). 
In most countries, such as Finland, the news coverage of climate change has been characterized by considerable increases and decreases. Based on the Finnish case, it is suggested that the climate debate has shifted to a new phase, where the coverage has fallen from peak levels but remains at a relatively high level and where climate issues are increasingly treated under other topics than environmental ones. These changes are likely to have profound implications to climate policy.

\section{Acknowledgment}

The study was supported by the Academy of Finland (The climate discussion on transport an interdisciplinary environmental analysis (CAST), project no.128307). Dr Vilja Varho provided highly useful comments for this article.

\section{References}

Adelekan, I. O. (2009). The Nigerian press and environmental information for sustainable development, Local Environment, Vol.14, No.4, pp. 297-312.

Ader, C. R. (1995). A Longitudinal Study of Agenda Setting for the Issue of Environmental Pollution, Journalism and Mass Communication Quarterly, Vol.72, No.2, pp. 300-311.

Alvarez, L. W., Alvarez, W., Asaro, F. \& Michel, H. V. (1980). Extraterrestrial Cause for the Cretaceous-Tertiary Extinction, Science, Vol.208, No.4448, pp. 1095-1108.

Armitage, K. C. (2005). State of Denial: The United States and the politics of global warming, Globalizations, Vol.2, No.3, pp. 417-427.

Baumgartner, F. \& Jones, B. D. (1993). Agendas and Instability in American Politics, Chicago, University of Chicago Press.

Berkhout, F. (2010). Reconstructing boundaries and reason in the climate debate, Global Environmental Change, Vol.20, No.4, pp. 565-569

Boyce, T. \& Lewis, J. (eds) (2009). Climate change and the media, New York, Peter Lang.

Boykoff, M. (2009). We Speak for the Trees: Media Reporting on the Environment, Annual Review of Environment and Resources, Vol.34, pp. 431-457.

Boykoff, M. \& Mansfield, M. (2010). Media Coverage of Climate Change/Global Warming. Center for Science and Technology Policy Research, University of Colorado \& University of Exeter, Oxford University. Available from: http://sciencepolicy.colorado.edu/media_coverage/.

Boykoff, M. T. \& Boykoff, J. M. (2007). Climate change and journalistic norms: A case-study of US mass-media coverage, Geoforum, Vol.38, No.6, pp. 1190-1204.

Brossard, D., Shanahan, J. \& McComas, K. (2004). Are issue-cycles culturally constructed? A comparison of French and American coverage of global climate change, Mass Communication \& Society, Vol.7, No.3, pp. 359-377.

Carvalho, A. \& Burgess, J. (2005). Cultural circuits of climate change in UK broadsheet newspapers, 1985-2003, Risk Analysis, Vol.25, No.6, pp. 1457-1469.

Curran, J., Iyengar, S., Brink Lund, A. \& Salovaara-Moring, I. (2009). Media System, Public Knowledge and Democracy, European Journal of Communication, Vol.24, No.1, pp. 526.

Dirikx, A. and Gelders, D. (2009). Global Warming through the same lens. An explorative framing study in Dutch and French newspapers, In: Boyce, T. \& Lewis, J. (eds) Climate change and the media, 200-210. New York, Peter Lang. 
Downs, A. (1972). Up and down with ecology: The "issue-attention" cycle, Public Interest, Vol.38, pp. 38-50.

Eide, E., Kunelius, R. \& Kumpu, V. (2009). Blame, domestication and elite perspectives in global media climate, Presentation at: Limits of Transnational Professionalism in Journalism. Global Dialogue Conference, Århus 4-6.11.2009.

Ekholm, P., Jutila, K. \& Kiljunen, P. (2007). Onpa ilmoja pidellyt - Ilmastonmuutos ja kansalainen (In Finnish: It has been quite a weather - climate change and citizen), Helsinki, Ajatuspaja e2. Available from :

http:/ / www.google.fi/url?sa=t\&source=web\&cd=1\&ved=0CBYQFjAA\&url=http \%3A\%2F\%2Fwww.e2.fi\%2Ffiles\%2FJulkaisut\%2520ja\%2520aineistot\%2FIlmastorap ortti012007.pdf\&ei=6VatTfDJAcSLswbzkOnXDA\&usg=AFQjCNGn97r2ySJclEngi3 dQsqZtr2n9mA

Eldredge, N. \& Gould, S. J. (1972). Punctuated equilibria: an alternative to phyletic gradualism, In : Schopf, T. J. M. (ed) Models in Paleobiology, 82-115. San Francisco, Freeman Cooper.

FABC (2010). Statistics. Finnish Audit Bureau of Circulations, Available from: http://www.levikintarkastus.fi/english/statistics.php.

Gamson, W. A. (1992). Talking politics, Cambridge, Cambridge University Press.

Haavisto, I. (2010). Työelämän kulttuurivallankumous (In Finnish: The cultural revolution of work life), Helsinki, Elinkeinoelmän valtuuskunta. Available from : http://www.tuottavuustyo.fi/tietoa/julkaisuja/evan_arvo-_ja_asennetutkimus_ 2010_tyoelaman_kulttuurivallankumous.html

Heiskala, R. (ed) (1993). Materiaalia ympäristötietoisuudesta 1: Helsingin Sanomat, Suomen Kuvalehti ja Suomen Luonto vuosina 1951-1990 (In Finnish: Material on environmental awareness 1: Environmental coverage in Helsingin Sanomat, Suomen Kuvalehti and Suomen Luonto, years 1951-1990), Helsinki, Helsingin yliopisto.

Herkman, J. (2010). Journalismi markkinoilla. Konserni- ja mediajournalismia (In Finnish: Journalism at markets. Conglomerate journalims and media journalism), In: Väliverronen, E. (ed) Journalismi murroksessa, 32-49. Helsinki, Gaudeamus Helsinki University Press.

Holt, D. \& Barkemeyer, R. (2010). Media coverage of sustainable development issues Attention cycles or punctuated equilibrium?', Sustainable Development, In Print, DOI: $10.1002 /$ sd.460.

Hopper, P. (2007). Understanding cultural globalization, Cambridge, Polity Press.

IPCC (2008). Climate Change 2007: Synthesis Report. Contribution of Working Groups I, II and III to the Fourth Assessment, Geneva, IPCC.

Juutilainen, H. (2001). Vain muutama tunti kesään - etelänmatkamainonta Helsingin Sanomissa 1965-1975 [In Finnish: Only few our to summer - advertising holiday trips in Helsingin Sanomat, 1965-1975], Helsinki, Helsingin Yliopisto, Talous- ja sosiaalihistoria.

Jylhä, K., Tuomenvirta, H. \& Ruosteenoja, K. ( 2004). Climate change projections for Finland during the 21st century, Boreal Environment Research, Vol.9, No.2, pp. 127-152.

Kantola, A. (1996). Tri Otsoni ja Mr Kasvihuone. Mediapaniikkeja kauhun rajamailta (In Finnish: Dr Ozone and Mr Greenhouse. Media panics from the edges of horror), In: Luostarinen, H., Kivikuru, U. and Ukkola, M. (eds) Sopulisilppuri. Mediakritiikin näkökulmia, 157-176. Lahti, Helsingin ylipiston Lahden tutkimus- ja koulutuskeskus. 
Karppinen, P. (1993). Kasvihuoneilmiön kasvu kuumaksi uutisaiheeksi Helsingin Sanomissa (In Finnish: The rise of greenhouse effect as a hot topic in the coverage of Helsingin Sanomat), Tampere, Tampereen yliopisto, Tiedotusopin laitos.

Kerkkänen, A. (2010). Ilmastonmuutoksen hallinnan politiikka. Kansainvälisen ilmastokysymyksen haltuunotto Suomessa (In Finnish: The politics of climate change governance. Reception of the international concern over climate change in Finland], Acta Universitatis Tamperensis; 1549, Tampere, Tampereen yliopisto. Available from: http:/ / acta.uta.fi/teos.php?id=11370

Kiljunen, P. (2010). Tiedebarometri 2010 (In Finnish: Science barometer 2010), Tieteen tiedotus Ry \& Yhdyskuntatutkimus Oy. Available from: http://www.sci.fi/ yhdys/tb4/tiedebaro4.htm

Kunnas, J. (2009). Fire and Fuels: CO2 and SO2 Emissions in the Finnish Economy, 1800-2005, Florence: European University Institute, Department of History and Civilization. Available from : http:/ / www.google.fi/url?sa=t\&source=web\&cd=1\&ved=0CBkQFjAA\&url=http \%3A\%2F\%2Fcadmus.eui.eu \%2Fbitstream\%2Fhandle\%2F1814\%2F11753\%2F2009_K unnasIntroduction.pdf\%3Fsequence\%3D1\&ei=KFatTcGuCdD2sgaw2Y3YDA\&usg $=$ AFQjCNGMzinfb5ZQMRpXUJWU2ady505k1w

Lebel, L. \& Lorek, S. (2008). Enabling Sustainable Production-Consumption Systems, Annual Review of Environment and Resources, Vol.33, pp.241-275.

Lyytimäki, J. (2007). Temporalities and environmental reporting: press news on eutrophication in Finland., Environmental Sciences, Vol.4, no.1, pp. 41-51.

Lyytimäki, J. (2009). Jälkeemme vedenpaisumus? Ilmastonmuutoksen ja merien suojelun ekologiset kynnysarvot (In Finnish: After us the deluge? Ecological tresholds of climate change and protection of the seas), Helsinki, Gaudeamus/Helsinki University Press.

Lyytimäki, J. (2011). Mainstreaming climate policy: The role of media coverage in Finland, Mitigation and Adaptation Strategies for Global Change, In Print, DOI: 10.1007/s11027011-9286-x.

Lyytimäki, J. \& Palosaari, M. (2004). Ympäristöviestinnän tutkimus Suomessa (In Finnish: Environmental communication research in Finland), Suomen ympäristö 683, ympäristöpolitiikka, Helsinki, Suomen ympäristökeskus. Available from: http:/ / www.ymparisto.fi/default.asp?contentid=70441\&lan=fi

Lyytimäki, J. \& Tapio, P. (2009). Climate change as reported in the press of Finland: From screaming headlines to penetrating background noise, International Journal of Environmental Studies, Vol.66, No.6, pp. 723-735.

Lähteenmäki, L. E. (2006). Ydinkokeista ydinvoimaan - unohtuiko ympäristö? (In Finnish: From nuclear tests to nuclear power - was the environment forgotten?), Helsinki, Helsingin yliopisto, Talous- ja sosiaalihistorian laitos.

Mazur, A. (1998). Global Environmental Change in the News, International Sociology, Vol.13, no.4, pp. 457-472.

Mazur, A. (2009). American generation of environmental warnings: Avian influenza and global warming, Human Ecology Review, Vol.16, No.1, pp. 17-26.

MEA (2005). Millennium Ecosystem Assessment. Ecosystems and Human Well-being: Synthesis, Washington, DC, Island Press.

Nerlich, B. (2010). 'Climategate': Paradoxical Metaphors and Political Paralysis, Environmental Values, Vol.19, No.4, pp. 419-442. 
Niemelä, J. (2008). 1700-luvun utilismi ja toive ilmaston lämpenemisestä (In Finnish: The utilims of 17th century and the hope of warmer climate), Auraica: Scripta a Societate Porthan edita, Vol.1, pp 71-80. Available from: http://ojs.tsv.fi/index.php/Aur/article/view/652

NOAA (2010). State of the Climate. Global Analysis January 2010. National Oceanic and Atmospheric Administration, National Climatic Data Center. Available from: http://www.ncdc.noaa.gov/sotc/global/2010/1

Olausson, U. (2009). Global warming - global responsibility? Media frames of collective action and scientific certainty, Public Understanding of Science, Vol.18, No.4, pp. 421436.

Oreskes, N. (2004). Beyond the Ivory Tower: The Scientific Consensus on Climate Change, Science, Vol.306, No.5702, p. 1686.

Painter, J. (2010). Summoned by science. Reporting Climate Change at Copenhagen and Beyond, Oxford, Reuters Institute for the Study of Journalism, University of Oxford.

Perimäki, A. (2002). Päästökatto, talouden rajat ja energian tarve. Suomalaisen energiakeskustelun muotoutuminen (In Finnish: Emission ceiling, limits of the economy and the need of energy. The shaping of Finnish energy debate), Yhteiskuntapolitiikka, Vol.67, No.2, pp. 148-161.

Reineck, E. (2009). Auto, luonnollisesti. Luonto, uhka ja ympäristönsuojelu vihreässä automainoksessa [In Finnish: The car, naturally. Nature, threat and environmental protection in green car advertisement], Tampere, Tampereen yliopisto, tiedotusopin laitos. Available from:

http:/ / tutkielmat.uta.fi/tutkielma.php?id=20166

Rinkinen, J. (2010). Liikenne mediassa: Kilpailevat tulevaisuudet sähköautosta autottomuuteen [In Finnish: The future of traffic in the media: Competing visions from electric cars to a car free future), Suomen ympäristö 21/2010, Helsinki, Suomen ympäristökeskus. Available from: http:/ / www.ymparisto.fi/default.asp?contentid=370032\&lan=fi

Rinne, J. (2003). Miksi julkisuudessa ollaan niin eri mieltä ilmastonmuutoksesta? (In Finnish Why the public debate includes much disagreement on climate change?), Tieteessä Tapahtuu, Vol.21, No.2, pp. 38-43. Available from: www.tieteessatapahtuu.fi/032/rinne.pdf

Sairinen, R., Järvinen, S. \& Kohl, J. (2010). Ilmastonmuutoksen ja siihen sopeutumisen sosiaaliset vaikutukset maaseudulla (In Finnish: The social impacts of climate change and adaptation measures in the countryside). Reports and Studies in Social Sciences and Business Studies., no 1, Joensuu, Itä-Suomen yliopisto, Yhteiskuntatieteiden ja kauppatieteiden tiedekunta. Available from: http:/ / epublications.uef.fi/pub/urn_isbn_978-952-61-0170-5/

Seppälä, J., Mäenpää, I., Koskela, S., Mattila, T., Nissinen, A., Katajajuuri, J.-M., Härmä, T., Korhonen, M.-R., Saarinen, M. \& Virtanen, Y. (2009). Suomen kansantalouden materiaalivirtojen ympäristövaikutusten arviointi ENVIMAT-mallilla (In Finnish: Assessment of the environmental impacts of material flows caused by the Finnish economy with the ENVIMAT model), Suomen ympäristö 20/2009, Helsinki, Suomen ympäristökeskus. Available from: http:/ / www.ymparisto.fi/ default.asp?contentid=334235\&lan=fi

Stern, N. (2007). The economics of climate change. The Stern review, Cambridge, Cambridge University Press. 
Suhonen, P. (1994). Mediat, me ja ympäristö (In Finnish: Media, us and the environment), Helsinki, Hanki ja jää.

Teräväinen, T. (2010). Ecological Modernisation and the Politics of (Un)Sustainability in the Finnish Climate Policy Debate, In: Simard, S. W. \& Austin, M. E. (eds) Climate Change and Variability, 409-426. Rijeka, Sciyo Publishing. Available from http://www.intechopen.com/articles/show/title/ecological-modernisation-andthe-politics-of-un-sustainability-in-the-finnish-climate-policy-debate

Tirkkonen, J. (2000). Ilmastopolitiikka ja ekologinen modernisaatio. Diskursiivinen tarkastelu suomalaisesta ilmastopolitiikasta ja sen yhteydestä metsäsektorin muutokseen (In Finnish: Climate Policy and Ecological Modernisation - A discursive study of Finnish Climate Policy and its connection to the change in the forest sector). Acta Universitatis Tamperensis 781, Tampere, Tampereen yliopistopaino. Available from: http:/ / acta.uta.fi/teos.php?id=4382

Udo, V. E. \& Jansson, P. M. (2009). Bridging the gaps for global sustainable development: A quantitative analysis, Journal of Environmental Management, Vol.90, No.12, pp. 37003707.

Ungar, S. (1992). The rise and relative decline of global warming as a social problem, Sociological Quarterly, Vol. 33, No.4, pp. 483-501.

Uusi-Rauva, C. \& Tienari, J. (2010). On the relative nature of adequate measures: Media representations of the EU energy and climate package, Global Environmental Change, Vol.20, no.3, pp. 492-501.

Weart, S. (2008). The Discovery of Global Warming. Revised and Expanded edition, Cambridge, MA, Harvard University Press.

von Storch, H. \& Krauss, W. (2005). Culture contributes to perceptions of climate change, Nieman Reports, Vol.59, No.4, pp. 99-102.

Väliverronen, E. (1996) Ympäristöuhkan anatomia (In Finnish: The anatomy of environmental threat), Tampere, Vastapaino.

YLE (2010). Liki joka toinen epäilee tietoja ilmastonmuutoksesta liioitteleviksi (In Finnish: Almost one out of two suspect that the information about climate change is exaggerating). National Broadcast Company (YLE). Available from

http://yle.fi/uutiset/kotimaa/2010/03/liki_joka_toinen_epailee_tietoja_ilmaston muutoksesta_liioitteleviksi_1565588.html 


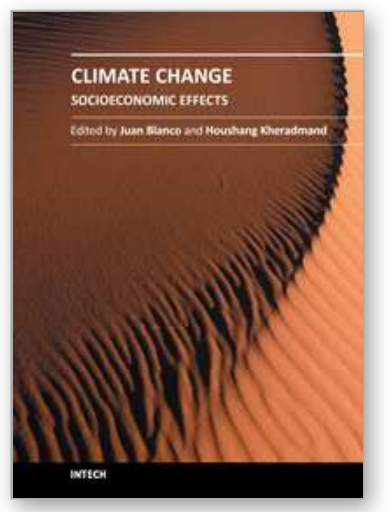

\author{
Climate Change - Socioeconomic Effects \\ Edited by Dr Houshan Kheradmand
}

ISBN 978-953-307-411-5

Hard cover, 454 pages

Publisher InTech

Published online 09, September, 2011

Published in print edition September, 2011

This book shows some of the socio-economic impacts of climate change according to different estimates of the current or estimated global warming. A series of scientific and experimental research projects explore the impacts of climate change and browse the techniques to evaluate the related impacts. These 23 chapters provide a good overview of the different changes impacts that already have been detected in several regions of the world. They are part of an introduction to the researches being done around the globe in connection with this topic. However, climate change is not just an academic issue important only to scientists and environmentalists; it also has direct implications on various ecosystems and technologies.

\title{
How to reference
}

In order to correctly reference this scholarly work, feel free to copy and paste the following:

Jari Lyytimäki (2011). Hitting the Headlines and Falling Down Again: Newspaper Coverage of Climate Change in Finland, Climate Change - Socioeconomic Effects, Dr Houshan Kheradmand (Ed.), ISBN: 978-953-307-4115, InTech, Available from: http://www.intechopen.com/books/climate-change-socioeconomic-effects/hitting-theheadlines-and-falling-down-again-newspaper-coverage-of-climate-change-in-finland

\section{INTECH}

open science | open minds

\section{InTech Europe}

University Campus STeP Ri

Slavka Krautzeka 83/A

51000 Rijeka, Croatia

Phone: +385 (51) 770447

Fax: +385 (51) 686166

www.intechopen.com

\section{InTech China}

Unit 405, Office Block, Hotel Equatorial Shanghai

No.65, Yan An Road (West), Shanghai, 200040, China

中国上海市延安西路65号上海国际贵都大饭店办公楼405单元

Phone: +86-21-62489820

Fax: $+86-21-62489821$ 
(C) 2011 The Author(s). Licensee IntechOpen. This chapter is distributed under the terms of the Creative Commons Attribution-NonCommercialShareAlike-3.0 License, which permits use, distribution and reproduction for non-commercial purposes, provided the original is properly cited and derivative works building on this content are distributed under the same license. 